\title{
Chemical and Biological Evaluation of Some Products from Quinoa-Based Blends for Celiac Disease
}

\author{
El-Sebeay, A.S. \& Lamia M. Hafez \\ Regional Center for Food and Feed, Agricultural Research Center, Alexandria, Egypt.
}

Received: 26 February, 2018

Revised: 10 April, 2018

Accepted: 8 May, 2018

\begin{abstract}
Celiac disease (CD) is a longevity food intolerance to gluten. Quinoa has complete nutritional characteristics and is gluten free, so it is tolerable for $\mathrm{CD}$. The objective of this study was to estimate chemical, sensory and biological evaluation of some formulated quinoa products as an alternative food suggested for CD. Quinoa, rice, corn, chick-pea flours and their products (cake, biscuit and toast) in different ratio were prepared and examined for sensory properties. It was found that; the best acceptable blends were quinoa flour: rice flour: corn flour with rito 1:1:1 in cake and toast and quinoa flour: rice flour: chick-pea flour with rito 1:1:1in biscuit. Biological evaluation was done on 32 albino male rates classified into four equal groups of eight rats each. Group 1 was the control group, the other groups were fed on the products for 8 weeks. Weight gain and relative organ weights were estimated. Blood picture, lipid profile, alanine transaminase (ALT), aspartate transaminase (AST), total protein, albumin, bilirubin, creatinin, uric and glucose were estimated. The results revealed that quinoa flour was free of gluten and the percentage of saponin after washing was $0.2 \%$. Quinoa flour had $16.4 \%$ protein, $8.2 \%$ fat and was rich in $\mathrm{Ca}, \mathrm{P}, \mathrm{Na}, \mathrm{K}, \mathrm{Mg}$ and $\mathrm{Cu}$. The percentage of some essential amino acids in quinoa flour surpassed the FAO model. Quinoa flour had low percentage of saturated and monounsaturated fatty acids, but it had high contents of polyunsaturated fatty acids $\omega 6$ and $\omega 3$. Cake and biscuit were higher in protein, fat and fiber than toast, while toast was the highest in minerals content except for $\mathrm{Cu}$. The biological evaluation for the three products showed that; the weight gain decreased in all the treated groups. All the parameters of the blood tests were as that of the control except for the hemoglobin level. Total lipids, cholesterol, triglycerides and low density lipoprotein (LDL) were higher in cake fed group than the control group. Liver functions and kidney functions were not affected by feeding on the products; there were no differences in AST and bilirubin levels between the treated groups. Further research, including human clinical trials, is needed and recommended.
\end{abstract}

Key words: Quinoa, Celiac disease, rats, alternative food.

\section{INTRODUCTION}

Celiac disease (CD) is a longevity food intolerance to gluten. Its prevails is $1 \%$ of the Westerns populations (Lohi et al., 2007).CD is an immunemediated chronic disorder in some individuals, resulted from the ingestion of some wheat proteins generally known as "gluten" and similar alcoholsoluble proteins (prolamins) of rye and barley. The disease is characterized by enteropathy with small-intestinal villous atrophy, which leads to malabsorption. Strict elimination of gluten-containing cereals from the diet was the only acceptable treatment for $\mathrm{CD}$, which results in the recovery of most individuals (Catassi \& Fasano, 2008).

However, there is an increasing concern regarding the long term dietary habits and food choices of celiac patients and many studies found that gluten-free diet (GFD) does not provide an adequate nutritional intake (Miranda et al., 2014). Deficiencies were noticed in dietary fiber, complex carbohydrates, minerals and vitamins after treatment with a long-term GFD (Wild et al., 2010).
These deficiencies are related to the content of starch or refined flours in gluten-free foods, which is low in fibers and vitamins B group (Thompson et al., 2005).

Moreover, Lucisano et al. (2012) reported that most gluten-free products (GFP) had poor cooking quality compared with their wheat counterparts. Also, there is a need to improve the nutritional and sensory quality of GFP. Pseudo-cereals such as amaranth, buckwheat and quinoa are valuable alternatives to gluten-containing grains for manufacturing GFP, because they provide good quality protein, dietary fibers and unsaturated fatty acids. The market for GFP has shown a compound annual growth rate of $28 \%$ over the 2008 - 2012 period, reaching $\$ 4.2$ billion in 2012 in the US market (Packaged Facts, 2012).

Recent in-vitro studies suggest that quinoa complies with the Codex Alimentarius nomenclature of GFP (gluten $<20 \mathrm{mg} / \mathrm{kg}$ ), and is potentially suitable for patients with $\mathrm{CD}$ after examining one unknown cultivar in human T cells and organ culture explants (Bergamo et al., 2011). 
Quinoa (Chenopodium quinoa Willd.) is one of a multipurpose agricultural crop. The seeds may be utilized for human food, in flour products and in animal feed stock regarding to its high nutritive value (Repo-Carrasco et al., 2003). FAO considered quinoa as one of the crops to offer food security in the next century (Jacobsen, 2003).

Quinoa is a starchy dicotyledonous seed, and therefore not a cereal, so it is known as a pseudocereal (USDA, 2005). It is free of gluten, so it can be eaten by people who have CD as well as by those who are allergic to wheat. Quinoa seeds are very nourished and a source of good quality protein (Abugoch et al., 2008), lipids (Koziol, 1993), starch (Coulter \& Lorenz, 1990), minerals (Oshodi et al., 1999) and vitamins likes vitamin B (Koziol, 1993).

A previous study, suggested some alternative products for $\mathrm{CD}$ children from rice flour, corn flour and chick-pea flour (Hafez \&Mostafa 2014) but some cases were diabetic so they can't eat much rice. Emily et al.,(2012) reported a significant risk increase of type 2 diabetes with the high consumption of white rice, because the glycemic index of white rice is higher on average than in whole grains, which means that it could cause spikes in blood sugar (Foster-Powell et al.,2002). On the other hands quinoa maintains a low glycemic index (Atkinson et al., 2008).The present study aimed to prepare and evaluate (chemically, sensory, and biologically) some alternative food from quinoa flour mixed with rice, corn and chick-pea flours to be more nourished and tolerable for celiac disease.

\section{MATERIALS AND METHODS}

\section{Materials}

Quinoa seeds were purchased from Egyptian Natural Oils Company - Cairo - Egypt and the other ingredients; namely, rice, corn and chick-pea flours were purchased from a local market in Alexandria city.

\section{Sample preparation}

Quinoa seeds were cleaned from dust and other contaminants by using a grain separator (The Hance Corporation, Westville, Ohio, USA. Model100). The seeds were then scrubbed and polished using a pulper (Langsenkamp, Indianapolis, Indiana, model 5707), equipped with a sieve with holes of $0.08 \mathrm{~cm}$ in diameter. The seeds were then washed with tap water in a tank equipped with a mixer to remove saponin. After $45 \mathrm{~min}$. of washing, the seeds were rinsed and dried in air driven an oven at $40^{\circ} \mathrm{C} \sim$ for $12 \mathrm{hr}$. Finally the seeds were milled (Tecator, Cyclotec 1093 Sample Mill) before analysis (particle size 40-60mesh).

Good quality of corn, rice and chick-pea flours were mixed with quinoa flour at different ratios to prepare some alternative food as cake, biscuit and toast. Many products had been made at different ratios and were subjected to sensory evaluation. Three products had high scores in the sensory evaluation. These three products were made from quinoa, corn and rice flours (cake and toast) at ratio 1:1:1, quinoa, chick-pea and rice flours (biscuit) at ratio 1:1:1. Weight of each product and the cost per $100 \mathrm{~g}$ were estimated (Table 1).

\section{Methods}

\section{Gluten index and saponin}

Quinoa flour was analyzed for gluten index, according to the AACC (2000), while saponin was determined according to Obadoni \& Ochuko (2001).

\section{The proximate analysis and gross energy:}

Quinoa flour and quinoa- based products were analyzed for proximate composition according to the AOAC (2007) for protein, fat, crude fiber, ash, moisture, while carbohydrates were calculated by difference. Total dietary fibers content was determined according to Lee et al., (1992) and gross energy was done by Isoperibol Bomb Calorimeter, as described by the method of the AOAC, (1995).

\section{Minerals \& Vitamins contents:}

$\mathrm{Ca}, \mathrm{P}, \mathrm{Na}, \mathrm{K}, \mathrm{Mg}$ as $\mathrm{mg} / 100 \mathrm{~g}$ and $\mathrm{Cu}, \mathrm{Zn}$ contents as ppm were determined in quinoa flour and products according to the AOAC (2007) with an Atomic Absorption Spectrophotometer apparatus (Perking Elmer, model 5100PC). Vitamins B1 and $\mathrm{B} 2$ in quinoa flour and products were analyzed by Using Danish official, HPLC methods. (National Food Agency of Denmark, 1996).

\section{Amino acids \& Fatty acids composition:}

Amino acid composition in quinoa flour and products were estimated as described by the AOAC (2006a).Fatty acid composition in quinoa flour and products were esterified into their corresponding fatty acid methyl esters (FAMEs) using methanolic $\mathrm{NaOH}$ and boron tri fluoride (BF3) with methanol as described by the AOAC (2006b). 
Table 1: Ingredients, preparation, weight and costs of quinoa-based blends (cake, biscuit and toast)

\begin{tabular}{|c|c|c|c|}
\hline Samples & Cake & Biscuit & Toast \\
\hline \multirow[t]{10}{*}{ Ingredients } & - 1 cup white rice flour & - 1 cup white rice flour & - 1 cup white rice flour \\
\hline & - 1 cup quinoa flour & - 1 cup quinoa flour & - 1 cup quinoa flour \\
\hline & - 1 cup corn flour & - 1 cup chick-pea flour & - 1 cup corn flour \\
\hline & $-2 / 3$ cup butter and corn oil & $-2 / 3$ cup butter & -2 f spoon corn oil \\
\hline & -1 cup sugar & - 1 cup sugar & $-1 \mathrm{t}$ spoon salt \\
\hline & - 1 cup milk & - $1 / 2$ cup milk & - 1 cup milk \\
\hline & - 3 f spoon baking soda & - 3 f spoon baking soda & - 3 f spoon baking soda \\
\hline & -3 eggs & -3 eggs & - \\
\hline & $-1 / 4$ t spoon vanilla & - 1/4 t spoon vanilla & - \\
\hline & - 3 f spoon xanthan gum & & - 3f spoon xanthan gum \\
\hline \multirow[t]{7}{*}{ Preparation } & $\begin{array}{l}\text {-Mix butter, oil and sugar } \\
\text { carefully. }\end{array}$ & $\begin{array}{l}\text {-Peat sugar with butter care- } \\
\text { fully. }\end{array}$ & $\begin{array}{l}\text {-Mix rice, quinoa and corn } \\
\text { flour together. }\end{array}$ \\
\hline & $\begin{array}{l}\text { - Peat egg well in addition } \\
\text { to vanilla then add to the } \\
\text { former mixture. }\end{array}$ & $\begin{array}{l}\text { - Add egg with vanilla and } \\
\text { mix it. }\end{array}$ & $\begin{array}{l}\text { - Add salt, baking soda and } \\
\text { xanthan gum to the former } \\
\text { mixture. }\end{array}$ \\
\hline & - Add milk. & - Add milk. & - Add corn oil. \\
\hline & $\begin{array}{l}\text { - Add rice, quinoa and corn } \\
\text { flour gradually with baking } \\
\text { soda and xanthan gum and } \\
\text { mix well. }\end{array}$ & $\begin{array}{l}\text { - Add rice, chick-pea and qui- } \\
\text { noa flour with baking soda } \\
\text { gradually. }\end{array}$ & - Add milk and mix well. \\
\hline & $\begin{array}{l}\text { - Pour the mixture in a tray } \\
\text { lined with fat and rice flour. }\end{array}$ & $\begin{array}{l}\text { - Form biscuits in different } \\
\text { forms. }\end{array}$ & $\begin{array}{l}\text { - Pour the mixture in a tray } \\
\text { lined with fat and rice flour. }\end{array}$ \\
\hline & $\begin{array}{l}\text { - Bake in moderate oven at } \\
180{ }^{\circ} \mathrm{C} / 30 \mathrm{~m} \text {. }\end{array}$ & $\begin{array}{l}\text { - Bake in moderate oven at } \\
180^{\circ} \mathrm{C} / 30 \mathrm{~min} .\end{array}$ & $\begin{array}{l}\text { - Spread } 1 \mathrm{t} \text { spoon corn oil on } \\
\text { the surface. }\end{array}$ \\
\hline & & & $\begin{array}{l}\text { - Bake in moderate oven at } \\
200^{\circ} \mathrm{C} / 40 \mathrm{~m} \text {. }\end{array}$ \\
\hline Weight of product & $1650 \mathrm{~g}$ & $1370 \mathrm{~g}$ & $1085 \mathrm{~g}$ \\
\hline Costs $/ 100 \mathrm{~g}$ & $1.92 \mathrm{Pt}$ & $2.45 \mathrm{Pt}$ & $1.85 \mathrm{Pt}$ \\
\hline
\end{tabular}

\section{Sensory evaluation:}

The quality scores for the most acceptable three products were conducted. The products were served to 15 panelist and $10 \mathrm{CD}$ children on three separate days; they had to score of 10 for colour, flavour, taste, texture and general acceptability. The mean score of each product was determined according to Walts, et al. (1989).

\section{Experimental animals}

Male albino rats $(n=32)$ averaging $200 \pm 5 \mathrm{~g}$ of BW were obtained from the animal house of the High Graduated Studies Institute, University of A1exandria, Egypt. The design of the experiments and the protocol follows the international guidelines and the ethics of the National Institutes of Health (2005).Animals received human care, and had adequate stable diet and water ad lipitum. Animals were acclimatized to the laboratory conditions for two weeks before being experimented. All laboratory biological specimens and hazardous waste were disposed safely.

\section{Experimental design:}

After two weeks of acclimation, animals were classified into four equal groups of eight rats each. Group1 (control group) was fed on conventional food all over the experimental period (sucrose $50 \%$, casein $20 \%$, corn starch $15 \%$, corn oil $5 \%$,cellulose 5\%, mineral mix 3.5\%,vitamin mix 1\%, DLmethionine $0.3 \%$ and choline bitartrate $0.2 \%$ ) as described by the National Academy of Sciences, (1995). Group 2,3and 4 were fed on cake, biscuit and toast, respectively for 8 weeks.

\section{Body weight and organs weight:}

Body weight of rats was recorded in the beginning and at the end of the experimental period. Animals were sacrificed by decapitation, and then liver, 
kidney, brain, testes, heart, lung and spleen were immediately removed and weighed. Relative organ weights were calculated as $\mathrm{g} / 100 \mathrm{~g}$ body weight.

\section{Blood sample:}

Blood samples were collected from the sacrificed animals in two separate tubes, one of them contained heparin. Plasma samples were obtained by centrifugation at $4000 \mathrm{rpm}$ for 20 minutes, and then samples were stored at $-20^{\circ} \mathrm{C}$ until used for further analyses.

\section{Lipid profile:}

Plasma samples were analyzed for cholesterol and triglycerides according to the methods of Tietz (1995), high-density lipoprotein-cholesterol (HDL-c) was determined according to the methods of Sugiuchi et al., (1995), low-density lipoproteincholesterol (LDL-c) was determined by the method of Pisani et al., (1995) and very low-density lipoprotein-cholesterol (VLDL-c) was calculated automatically by Roche /Hitachi Cobas C systems.

\section{Enzymes activity and biochemical param- eters:}

The activities of plasma alanine transaminase (ALT) and aspartate transaminase (AST) were assayed by the method of Bergmeyer \& Horder (1986).Total protein and albumin were determined by the method of Doumas et al.,(1977), total bilirubin was measured using the method of Wahlefeld \& Bergmeyer (1972).Uric acid and creatinine concentrations were measured according to the method of Lamb et al., (2006), while glucose content was analyzed according to Kunst et al.,(1984).All the aforementioned parameters were measured using commercial kits, [Bio systems S.A. (Spain), Diamond (Germany) and Randox (United Kingdom)].

\section{Statistical analysis:}

All data were expressed as mean \pm SD. Statistical Analyses System (SAS) software program version 9.1 (SAS, 2003) was used for one-way analysis of variance (ANOVA), at $\leq 0.05$ to compare the statistical significant difference between groups.

\section{RESULTS \& DISCUSSION}

Quinoa has attracted attention in the last years not only for its excellent nutritional value, but also it contains high amounts of proteins, fibers, minerals, vitamins and $\omega-3$ fatty acids (Vega-Galvez et al., 2010).
Table (2) summarizes the chemical analysis of quinoa flour. Quinoa flour was examined for its content of gluten and saponin before use in preparing some products. Quinoa flour was free of gluten and the saponin content before and after washing was $0.38 \%$ and $0.2 \%$, respectively. Güçlü-Üstünda \& Mazza (2007) reported that the saponin content in quinoa of some types varied from $0.02 \%$ to $0.04 \%$ and in other types from $0.14 \%$ to $2.3 \%$.As presented in Table (2) quinoa had $16.4 \%$ protien, $8.2 \%$ fat, and is rich in $\mathrm{Ca}, \mathrm{P}, \mathrm{Na}, \mathrm{K}, \mathrm{Mg}, \mathrm{Cu}$ and Zn being 50, 440, 80, 660, $200 \mathrm{mg} / 100 \mathrm{~g}, 36.1$ and $16.1 \mathrm{ppm}$, respectively. Vitamins B1 and B2 in quinoa flour were 0.34 and $0.14 \mathrm{mg} / \mathrm{g}$.

Nascimento et al. (2014) also found that quinoa had higher protein content than common gluten-free cereals such as corn and rice, and is comparable to that of wheat. In addition, ValenciaChamorro (2003) reported that, the percentage of protein in quinoa seed varies from $8 \%$ to $22 \%$, which is higher on average than that in common cereals such as rice, wheat, and barley. Ruales \& Nair (1993) also found that quinoa had larger amounts of $\mathrm{Ca}, \mathrm{P}, \mathrm{Mg}$ and $\mathrm{K}$ than most of the common cereal grains. The National Academy of Sciences, 2004 reported that; B2 content in $100 \mathrm{~g}$ contributes $80 \%$ of the children's daily needs and $40 \%$ of those of adults. B1 values in quinoa are lower than those in oat or barley.

Table (2) also represents the main amino acids of quinoa flour, it was found that the flour contained high percentage of the essential amino acids (EAA) (therionene, isoleucine, valine, leucine, phenylalanine, histidine, lysine and methionine $4.8,4.8,6.2,8.9,5.7,4.2,7.0$ and 3.5\%), respectively. Some EAA were in higher percentage than that of the FAO model as therionene, isoleucine, valine, histidine and lysine (4.3, 4.6, 5.5, 2.6 and $6.6 \%$ ), respectively. Bhargava et al., (2003) reported that; the EAA balance in quinoa flour is excellent because of a wider amino acids range than in cereals and legumes, with higher lysine (5.1-6.4\%) and methionine (0.4-1\%) contents. Also quinoa has higher histidine content than soy, barley, or wheat proteins. The methionine and cysteine content of quinoa is sufficient for children (2-12 years old) and adults. In addition, quinoa proteins contain very little prolamins, which are the toxic proteins in CD (Drzewiecki et al., 2003).

Table (2) also reveals that quinoa flour had low percentage of the saturated fatty acids (SFAs) 
mainly palmaitic acid, $\mathrm{C} 16: 0(11.8 \%)$ and the monounsaturated fatty acids (MUFAs) mainly oleic acid, C18:1 $\omega 9$ (32.64\%), and it had high contents of the polyunsaturated fatty acids (PUFAs) mainly linoleic acid, C18:2 $\omega 6$ (51.99\%). Also, it is clear that quinoa flour has a high level of $\omega 6$ and $\omega 3$ fatty acids. Some researchers have characterized fatty acids of quinoa lipid as follows: total SFAs $19-12.3 \%$, mainly palmitic acid; total MUFAs 25$28.7 \%$, mainly oleic acid, and total PUFAs $58.3 \%$ chiefly linoleic acid about 90\% (Ryan et al., 2007). Repo-Carrasco (2003) also found that palmitic acid is the major SFA found in quinoa, constituting $10 \%$ of the total fatty acids, while MUFA oleic (19.729.5\%), linoleic (49.0-56.4\%) and alpha-linolenic (8.7-11.7\%) acids represent $88 \%$ of the total fatty acids of quinoa. Essential fatty acids are important acids, like linoleic and linolenic acids, which are necessary in animal metabolism.

Table (3) represents chemical analysis for the three products (cake, biscuit and toast), it was found that; cake and biscuit were higher in protein (12.8 and $12.2 \%$ ), fat (18.5 and 20.4\%) and fiber (7.4 and 3.3\%) than toast (11.6, 12.4 and $2.8 \%$ ), respectively. The protein and fat contents in cake and biscuit in this study were found to be higher than those of a previous study by Hafez \&Mostafa (2014), this may be because the high content of protein and fat of quinoa flour. For minerals contents it was found that every $100 \mathrm{~g}$ of cake, biscuit and toast can supply with $(100,60$ and $110 \mathrm{mg})$ $\mathrm{Ca},(380,360$ and $490 \mathrm{mg}) \mathrm{P},(240,280$ and $360 \mathrm{mg})$ $\mathrm{K},(70,60$ and $110 \mathrm{mg}) \mathrm{Mg},(23,26$ and $25 \mathrm{ppm})$ $\mathrm{Cu}$, and $(115,103$ and $146 \mathrm{ppm}) \mathrm{Zn}$ respectively. In general toast had high percentages of all the minerals except for $\mathrm{Cu}$. Vitamin B1 was higher in cake than biscuit and toast while biscuit was the highest in $\mathrm{B} 2$ content

Biscuit had significant high percentage of some EAA as lysine, histidine and phenylalanine $(6.4,3.3$ and $6.4 \%)$, respectively, while cake was higher (but not significant) in methionine and leucine (3.3 and 9.3\%), respectively. For fatty acids it was found that biscuit was higher of SFAs, MUFAs and PUFAs (33.64, 36.81 and 49.23\%) than cake $(24.36,33.23$ and $41.3 \%)$ and toast $(18.73,31.84$ and $28.59 \%$ ), which represent the lowest percent (Table 3).

Sensory evaluations were conducted on the three products by 15 panelists and 10 celiac disease children on three separated days .Mean scores for colour, flavour, taste, texture and general acceptability were recorded and given in Table (4). Biscuit possessed the significantly highest score in acceptability (8.9) followed by cake (8.5) then toast (7.8).

Table (5) reveals that there was a significant difference change in body weight gain for all the tested groups, the biscuit fed group was extremely close to the control group (44.4 and $48.4 \mathrm{~g}$ ), respectively, but rats in the toast fed group had the lowest body weight gain (38.1g). Grant et al., (1995) also, found a positive relationship between decreased weight gain and consumption of quinoa in animals; it may be because the presence of saponins in quinoa which connected to decreased weight gain (Carlson et al., 2012). Feed intake was higher in cake and biscuit fed groups than the control group, while in toast fed group it was as the same as the control group. Feeding on biscuit resulted in the highest protein efficiency ratio $(0.43 \mathrm{~g} / \mathrm{kg})$ compared to the other products and conventional diet for rats. Other study demonstrated a net protein utilization value of 75.7 and a biological value of 82.6, for raw quinoa protein (Ruales \& Nair 1992).

From Table (6) it was found that there were no significant differences in relative weight change for liver, kidney, brain and lung, while there were slight differences in the relative weight of heart, testes and spleen.

Blood picture for control group and other experimental groups were mentioned in table (7), it was found no difference between control group and other experimental groups in all parameters (RBC, WBC, PLT, PCV, MCV, MCH, MCHC).But there was a difference in hemoglobin level between control group $(15.2 \mathrm{~g} / \mathrm{dl})$ and cake group $(13.3 \mathrm{~g} / \mathrm{dl})$, but the decrease was not significant in biscuit and toast groups.

Table (8) showed that the total lipid, cholesterol, triglycerides, LDL and VLDL were higher in rats fed on cake $(409,94,111,47.5$ and $22.2 \mathrm{mg} / \mathrm{dl})$, respectively than the control group and the other experimental groups. Toast represented the lowest level of total lipid, cholesterol and triglycerides $(388,81$ and $87 \mathrm{mg} / \mathrm{dl})$, respectively while LDL and VLDL were close to that of the control group. HDL was lower in all experimental fed groups than control groups, the lowest level of HDL was found in biscuit fed group. The increase in lipid profiles in the cake fed groups may be due to other components of the cake as egg, fat and milk. But in an- 


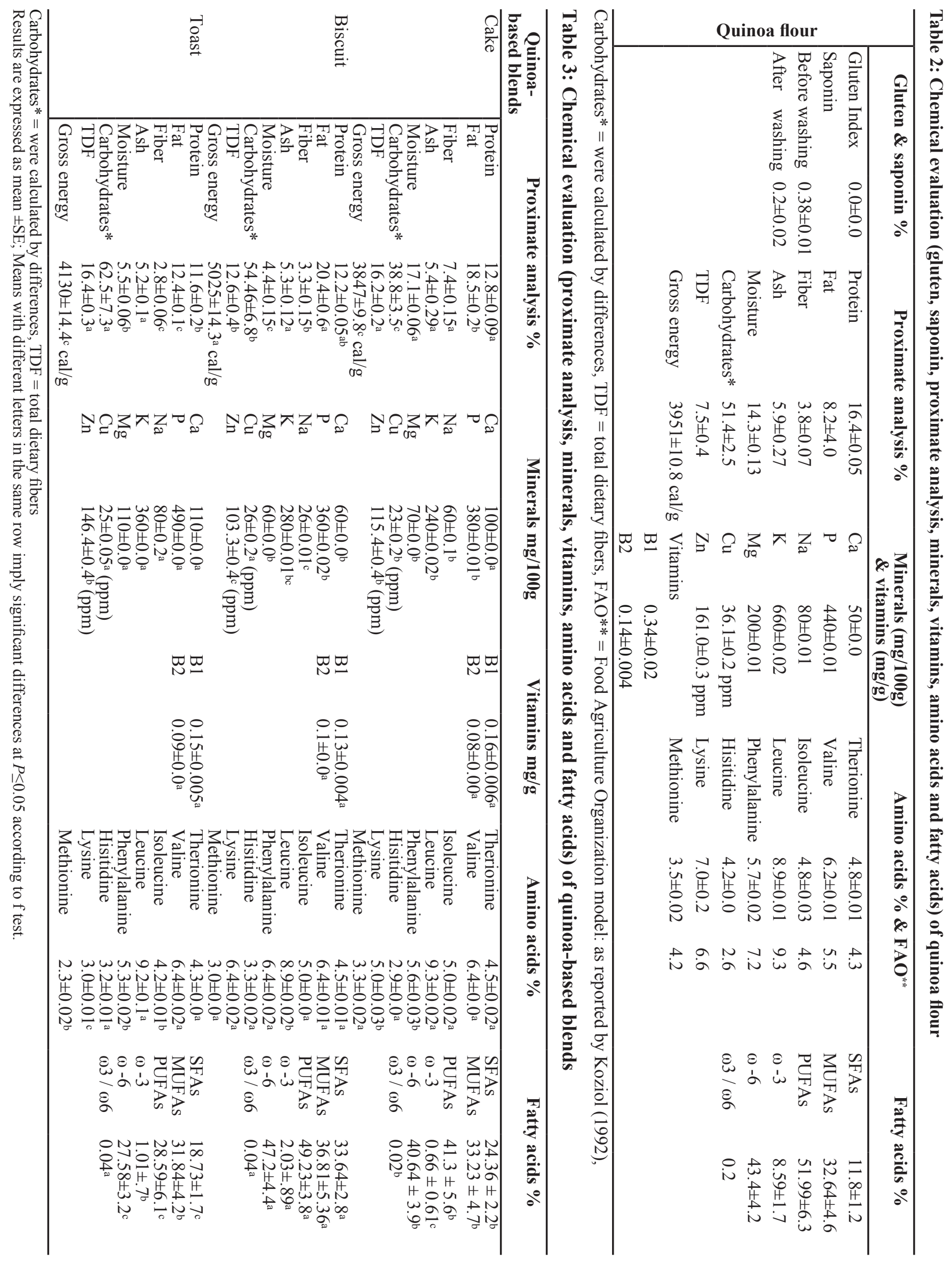


Table 4: Sensory evaluation of cake, biscuit and toast prepared from quinoa, rice, corn and chickpea flours

\begin{tabular}{lccccc}
\hline \multicolumn{1}{c}{ Products } & Colour & Flavour & Taste & Texture & General Acceptability \\
\hline Cake & $8.4 \pm 0.27^{\mathrm{a}}$ & $8.5 \pm 0.38^{\mathrm{a}}$ & $8.9 \pm 0.35^{\mathrm{a}}$ & $8.8 \pm 0.24^{\mathrm{a}}$ & $8.5 \pm 0.34^{\mathrm{ab}}$ \\
Biscuit & $9.0 \pm 0.23^{\mathrm{a}}$ & $8.7 \pm 0.37^{\mathrm{a}}$ & $8.9 \pm 0.31^{\mathrm{a}}$ & $9.0 \pm 0.27^{\mathrm{a}}$ & $8.9 \pm 0.29^{\mathrm{a}}$ \\
Toast & $8.4 \pm 0.24^{\mathrm{a}}$ & $7.8 \pm 0.33^{\mathrm{a}}$ & $8.4 \pm 0.20^{\mathrm{a}}$ & $7.8 \pm 0.26^{\mathrm{b}}$ & $7.8 \pm 0.35^{\mathrm{b}}$ \\
\hline
\end{tabular}

Results are expressed as mean \pm SE; Means with different letters in the same row imply significant differences at $P \leq 0.05$ according to f test.

Table 5: Changes in weight, weight gain, feed intake and protein efficiency ratio in experimental groups of rats

\begin{tabular}{lllll}
\hline \multirow{2}{*}{ Parameters } & \multicolumn{4}{c}{ Experimental groups } \\
\cline { 2 - 5 } & \multicolumn{1}{c}{ Control } & Cake fed & Biscuit fed & Toast fed \\
\hline Initial weight $(\mathrm{g})$ & $198.3 \pm 4.2 \mathrm{a}$ & $200.6 \pm 3.2 \mathrm{a}$ & $196.4 \pm 4.8 \mathrm{a}$ & $201.2 \pm 2.6 \mathrm{a}$ \\
Final weight $(\mathrm{g})$ & $246.7 \pm 5.9 \mathrm{a}$ & $240.7 \pm 5.7 \mathrm{~b}$ & $240.7 \pm 10.5 \mathrm{~b}$ & $239.3 \pm 6.6 \mathrm{~b}$ \\
Weight gain $(\mathrm{g})$ & $48.4 \pm 8.4 \mathrm{a}$ & $40.1 \pm 5.4 \mathrm{~b}$ & $44.3 \pm 8.7 \mathrm{a}$ & $38.1 \pm 6.0 \mathrm{~b}$ \\
Feed intake $(\mathrm{g})$ & $100.3 \pm 7.6 \mathrm{~b}$ & $105 \pm 8.9 \mathrm{a}$ & $104.4 \pm 8.2 \mathrm{a}$ & $100.6 \pm 7.7 \mathrm{~b}$ \\
Protein efficiency ratio & $0.30 \pm 0.05 \mathrm{~b}$ & $0.37 \pm 0.06 \mathrm{ab}$ & $0.43 \pm 0.08 \mathrm{a}$ & $0.41 \pm 0.08 \mathrm{a}$ \\
\hline
\end{tabular}

Results are expressed as mean $\pm \mathrm{SE}$; Means with different letters in the same row imply significant differences at $P \leq 0.05$ according to $\mathrm{f}$ test.

Table 6: Changes in the relative weight of organs $(\mathrm{g} / 100 \mathrm{~g} \mathrm{BW})$ in different experimental groups of rats

\begin{tabular}{lllll}
\hline \multirow{2}{*}{ Organs } & \multicolumn{3}{c}{ Experimental groups } \\
\cline { 2 - 5 } & \multicolumn{1}{c}{ Control } & Cake fed & Biscuit fed & Toast fed \\
\hline Liver & $2.3 \pm 0.14^{\mathrm{a}}$ & $2.7 \pm 0.18^{\mathrm{a}}$ & $2.4 \pm 0.14^{\mathrm{a}}$ & $2.6 \pm 0.16^{\mathrm{a}}$ \\
Kidney & $0.81 \pm 0.45^{\mathrm{a}}$ & $0.74 \pm 0.48^{\mathrm{a}}$ & $0.76 \pm 0.5^{\mathrm{a}}$ & $0.76 \pm 0.41^{\mathrm{a}}$ \\
Brain & $0.60 \pm 0.03^{\mathrm{a}}$ & $0.70 \pm 0.04^{\mathrm{a}}$ & $0.60 \pm 0.02^{\mathrm{a}}$ & $0.66 \pm 0.03^{\mathrm{a}}$ \\
Testes & $1.4 \pm 0.1^{\mathrm{ab}}$ & $1.42 \pm 0.08^{\mathrm{a}}$ & $1.17 \pm 0.04^{\mathrm{b}}$ & $1.37 \pm 0.07^{\mathrm{ab}}$ \\
Heart & $0.32 \pm 0.02^{\mathrm{a}}$ & $0.27 \pm 0.01^{\mathrm{ab}}$ & $0.24 \pm 0.02^{\mathrm{b}}$ & $0.28 \pm 0.02^{\mathrm{ab}}$ \\
Lung & $0.71 \pm 0.3^{\mathrm{a}}$ & $0.66 \pm 0.4^{\mathrm{a}}$ & $0.66 \pm 0.4^{\mathrm{a}}$ & $0.72 \pm 0.5^{\mathrm{a}}$ \\
Spleen & $0.39 \pm 0.03^{\mathrm{a}}$ & $0.29 \pm 0.02^{\mathrm{bc}}$ & $0.22 \pm 0.01^{\mathrm{c}}$ & $0.32 \pm 0.04^{\mathrm{ab}}$ \\
\hline
\end{tabular}

Results are expressed as mean $\pm \mathrm{SE}$; Means with different letters in the same row imply significant differences at $P \leq 0.05$ according to f test.

Table 7: Changes in the blood picture of the different experimental groups of rats

\begin{tabular}{lllll}
\hline \multirow{2}{*}{\multicolumn{1}{c}{ Parameters }} & \multicolumn{4}{c}{ Experimental groups } \\
\cline { 2 - 5 } & Control & Cake fed & Biscuit fed & Toast fed \\
\hline Hemoglobin $(\mathrm{g} / \mathrm{dl})$ & $15.2 \pm 0.4^{\mathrm{a}}$ & $13.3 \pm 0.8^{\mathrm{b}}$ & $13.9 \pm 0.3^{\mathrm{ab}}$ & $14.2 \pm 0.4^{\mathrm{ab}}$ \\
$\mathrm{RBC}$ count $\left(\times 10^{6} \mathrm{~L}\right)$ & $5.5 \pm 0.2^{\mathrm{a}}$ & $5.0 \pm 0.4^{\mathrm{a}}$ & $4.9 \pm 0.1^{\mathrm{a}}$ & $5.2^{\mathrm{a}} \pm 0.2^{\mathrm{a}}$ \\
WBC count $\left(\times 10^{3} \mathrm{~L}\right)$ & $8100 \pm 279^{\mathrm{a}}$ & $8000 \pm 480^{\mathrm{a}}$ & $7300 \pm 74^{\mathrm{a}}$ & $7900 \pm 387^{\mathrm{a}}$ \\
Platelets count $\left(\times 10^{3} \mathrm{~L}\right)$ & $279 \pm 19.1^{\mathrm{a}}$ & $286 \pm 11.8^{\mathrm{a}}$ & $256 \pm 20.3^{\mathrm{a}}$ & $263 \pm 28.8^{\mathrm{a}}$ \\
PCV $(\mathrm{g} / \mathrm{dl})$ & $48 \pm 2.7^{\mathrm{a}}$ & $49 \pm 3.8^{\mathrm{a}}$ & $46 \pm 3.6^{\mathrm{a}}$ & $47 \pm 2.4^{\mathrm{a}}$ \\
$\mathrm{MCV}(\mathrm{fL} /$ cell $)$ & $88 \pm 7.1^{\mathrm{a}}$ & $97 \pm 2.0^{\mathrm{a}}$ & $94 \pm 6.5^{\mathrm{a}}$ & $91 \pm 6.6^{\mathrm{a}}$ \\
$\mathrm{MCH}(\mathrm{Pg} / \mathrm{cell})$ & $27.9 \pm 1.3^{\mathrm{a}}$ & $26.7 \pm 1.0^{\mathrm{a}}$ & $28.6 \pm 0.25^{\mathrm{a}}$ & $27.5 \pm 1.4^{\mathrm{a}}$ \\
$\mathrm{MCHC}(\mathrm{gm} / \mathrm{dl})$ & $31.9 \pm 1.3^{\mathrm{a}}$ & $27.4 \pm 0.9^{\mathrm{a}}$ & $30.9 \pm 2.2^{\mathrm{a}}$ & $30.5 \pm 1.9^{\mathrm{a}}$ \\
\hline
\end{tabular}

$\mathrm{RBC}=$ red blood cell, $\mathrm{WBC}=$ weight blood cell, $\mathrm{PCV}=$ packed cell volume, $\mathrm{MCV}=$ mean corpuscular volume, $\mathrm{MCH}$

$=$ mean cell hemoglobin, $\mathrm{MCHC}=$ mean cell hemoglobin concentration .

Results are expressed as mean $\pm \mathrm{SE}$; Means with different letters in the same row imply significant differences at $P \leq 0.05$ according to $\mathrm{f}$ test. 
Table 8: Changes in the lipid profile of different experimental groups of rats

\begin{tabular}{lllll}
\hline \multirow{2}{*}{ Parameters } & \multicolumn{3}{c}{ Experimental groups } \\
\cline { 2 - 5 } & \multicolumn{1}{c}{ Control } & Cake fed & Biscuit fed & Toast fed \\
\hline Total Lipid (mg/dl) & $346 \pm 9.6^{\mathrm{b}}$ & $409 \pm 15.2^{\mathrm{a}}$ & $397 \pm 19.2^{\mathrm{ab}}$ & $388 \pm 27.0^{\mathrm{ab}}$ \\
Cholesterol (mg/dl) & $83 \pm 4.1^{\mathrm{ab}}$ & $94 \pm 3.0^{\mathrm{a}}$ & $82 \pm 3.8^{\mathrm{ab}}$ & $81 \pm 4.4^{\mathrm{b}}$ \\
Triglyceride (mg/dl) & $78 \pm 3.1^{\mathrm{b}}$ & $111 \pm 5.8^{\mathrm{a}}$ & $104 \pm 8.2^{\mathrm{ab}}$ & $87 \pm 12.6^{\mathrm{ab}}$ \\
HDL-c (mg/dl) & $42 \pm 9.3^{\mathrm{a}}$ & $29 \pm 4.1^{\mathrm{ab}}$ & $23 \pm 2.4^{\mathrm{b}}$ & $34 \pm 3.4^{\mathrm{ab}}$ \\
LDL-c (mg/dl) & $25.7 \pm 5.4^{\mathrm{b}}$ & $47.5 \pm 5.2^{\mathrm{a}}$ & $38 \pm 6.3^{\mathrm{ab}}$ & $26 \pm 4.0^{\mathrm{b}}$ \\
VLDL-c $(\mathrm{mg} / \mathrm{dl})$ & $15.6 \pm 1.4^{\mathrm{b}}$ & $22.2 \pm 2.1^{\mathrm{a}}$ & $20.8^{\mathrm{b}} \pm 1.9^{\mathrm{ab}}$ & $17.4 \pm 1.6^{\mathrm{b}}$ \\
\hline
\end{tabular}

Results are expressed as mean \pm SE; Means with different letters in the same row imply significant differences at $P \leq 0.05$ according to $\mathrm{f}$ test.

other study on rats fed on quinoa alone, the results indicated that, quinoa effectively reduced serum total cholesterol (26\%), LDL (57\%), and triglycerides $(11 \%)$, when compared to the control group (Paśko et al., 2010). Takao et al., (2005), proposed that the protein present within the quinoa reduced the reabsorption of bile acids and decreased cholesterol synthesis in the liver.

Liver and kidney functions were expressed by some enzymes activity and other parameters; as reported in Table (9). It was found that there were no significant differences in the AST and bilirubin levels between the control group and the experimental groups, but there was a slight significant difference in ALT level between the control group and the other experimental groups (58.7, 47.8, 44.8 and $54.3 \mathrm{U} / \mathrm{L}$ ) in cake, toast, biscuit and control group, respectively. A significant decrease was noticed in urea level in the experimental groups as compared with the control group $(44,44,53$ and $54 \mathrm{mg} / \mathrm{dl})$ in cake, biscuit, toast and control group, respectively. Creatinine level decrease significantly in the bis- cuit and toast fed groups (1.9 and $1.8 \mathrm{mg} / \mathrm{dl})$ than the control group but in cake fed group the creatinine level was equal to that of the control group $(2.3 \mathrm{mg} / \mathrm{dl})$. There were no significant differences in total protein and albumin level between the experimental groups and the control group, these results agree with those of Obatolu et al., (2003) who found that; total protein and albumin levels in rats fed on quinoa diet or other diets were within the normal range, because diets which were used in their study were protein sufficient. For glucose there was no difference in glucose levels among the different groups. But in a study of Pasko et al., (2010) when he compared quinoa fed groups with the control group, he could observe that quinoa seeds significantly decreased the level of glucose. According to Ardiansyah et al., (2006), chemical compounds presented in quinoa seeds as tocopherols and polyphenols, might be able to improve glucose level. The results of the present study suggested that these products had beneficial effect on the nutritional and health status for rats.

Table 9: Enzyme activities and biochemical parameters of different experimental groups of rats

\begin{tabular}{lllll}
\hline \multirow{2}{*}{ Parameters } & \multicolumn{3}{c}{ Experimental groups } \\
\cline { 2 - 5 } & \multicolumn{1}{c}{ Control } & Cake fed & Biscuit fed & Toast fed \\
\hline ALT U/L & $54.3 \pm 6.1^{\mathrm{ab}}$ & $58.7 \pm 3.1^{\mathrm{a}}$ & $44.8 \pm 2.3^{\mathrm{b}}$ & $47.8 \pm 3.0^{\mathrm{ab}}$ \\
AST U/L & $58.8 \pm 7.5^{\mathrm{a}}$ & $60.3 \pm 0.63^{\mathrm{a}}$ & $26.5 \pm 5.4^{\mathrm{a}}$ & $55 \pm 3.7^{\mathrm{a}}$ \\
Total Protein (g/dl) & $5.5 \pm 0.39^{\mathrm{a}}$ & $5.3 \pm 0.09^{\mathrm{a}}$ & $5.2 \pm 0.35^{\mathrm{a}}$ & $5.3 \pm 0.15^{\mathrm{a}}$ \\
Albumin (g/dl) & $3.4 \pm 0.1^{\mathrm{b}}$ & $3.6 \pm 0.06^{\mathrm{ab}}$ & $3.8 \pm 0.06^{\mathrm{a}}$ & $3.8 \pm 0.09^{\mathrm{a}}$ \\
Total Bilirubin (mg/dl) & $0.48 \pm 0.05^{\mathrm{a}}$ & $0.42 \pm 0.03^{\mathrm{a}}$ & $0.4 \pm 0.05^{\mathrm{a}}$ & $0.39 \pm 0.02^{\mathrm{a}}$ \\
Urea (mg/dl) & $54 \pm 1.6^{\mathrm{a}}$ & $44 \pm 2.1^{\mathrm{b}}$ & $44 \pm 3.1^{\mathrm{b}}$ & $53 \pm 1.1^{\mathrm{a}}$ \\
Creatinine (mg/dl) & $2.3 \pm 0.25^{\mathrm{a}}$ & $2.3 \pm 0.07^{\mathrm{a}}$ & $1.9 \pm 0.04^{\mathrm{b}}$ & $1.8 \pm 0.08^{\mathrm{b}}$ \\
Glucose (mg/dl) & $103 \pm 3.9^{\mathrm{a}}$ & $119 \pm 1.3^{\mathrm{a}}$ & $107 \pm 6.8^{\mathrm{a}}$ & $100 \pm 8.8^{\mathrm{a}}$ \\
\hline
\end{tabular}

Results are expressed as mean $\pm \mathrm{SE}$; Means with different letters in the same row imply significant differences at $P \leq 0.05$ according to $\mathrm{f}$ test. 


\section{CONCLUSIONS}

Quinoa and quinoa products are important and tolerable especially for celiac disease (CD), in addition to their high nutritional value. Biological evaluation on rats in this study suggested that quinoa may have positive effects on different body systems and reduce risk of different chronic disorders. However, to date, few data demonstrating these health benefits are available, thus there is a need for further research to understand more about the biological effect of quinoa.

\section{REFERENCES}

AACC. 2000. Approved Methods of the American Association of Cereal Chemists, 10th ed. American Association of Cereal Chemists, St. Paul, MN.

Abugoch, L., Romero, N., Tapia, C., Silva, J. \& Rivera, M. 2008. Study of some physicochemical and functional properties of quinoa (Chenopodium quinoa Willd) protein isolates. Journal of Agricultural and Food Chemistry, 56:4745-4750.

AOAC. 1995. Official Methods of Analysis 16th ed. Association of Official Analytical Chemists. Arlington, VA.

AOAC.2006a. Official Methods of Analysis; Amino Acids Analysis Complete Amino Acid Profile (AAP)-item72.Association of Analytical Communities, Gaithersburg, MD, 17th edition, 2006. Reference data: Method 982.30 E (a,b,c); NFNAP; NITR; AA.

AOAC.2006b. Official Methods of Analysis: Lipids, Fats and Oils Analysis Fatty Acid Profile saturated, Mono and Polyunsaturated-item 2.Association of Analytical Communities, Gaithersburg, MD, 17th edition, 2006. Reference data: Method 965.49; NFNAP; LIPD; FA.

AOAC.2007. Official Methods of Analysis. 18th ed. AOAC, Arlington, VA.

Ardiansyah, S.H., Koseki, T., Ohinata, K., Hashizume, K. \& Komai, M. 2006. Rice bran fraction improves blood pressure, lipid profile, and glucose metabolism in stroke-prone spontaneously hypertensive rats. Journal of Agricultural and Food Chemistry, 54: 1914-1920.

Atkinson, F.S, Foster-Powell, K. \& Brand-Miller, J.C. 2008. International tables of glycemic index and glycemic load values. Diabetes Care, 31: 2281-2283.
Bergamo, P., Maurano, F. \& Mazzarella, G. 2011. Immunological evaluation of the alcohol-soluble protein fraction from gluten-free grains in relation to celiac disease. Molecular Nutrition and Food Research, 55: $1266-1270$.

Bergmeyer, H., Herder M, \& Rej, R.1986. Approved recommendation on IFCC methods for the measurement of catalytic concentration of enzymes. Part 3.IFCC Method for alanine amino transferase. Journal of Clinical Chemistry and Biochemistry, 24:481-495.

Bhargava, A., Shukla, S. \& Ohri, D. 2003. Genetic variability and heritability of selected traits during different cuttings of vegetable Chenopodium. The Indian Journal of Genetics and Plant Breeding, 63:359-360.

Carlson, D., Fernandez, J.A., Poulsen, H.D., Nielsen, B. \& Jacobsen, S.E. 2012. Effects of quinoa hull meal on piglet performance and intestinal epithelial physiology. Journal of Animal Physiology and Animal Nutrition, 96:198-205.

Catassi, C. \& Fasano, A. 2008. Celiac disease. In: Gluten-free cereal products and beverages, Arendt E.K. \& Bello D.F (Eds). Academic Press Burlington, MA 01803, USA.

Coulter, L. \& Lorenz, K. 1990. Quinoa composition, nutritional value, food applications. Lebensmittel-Wissenschaft und-Technologie, 23: 203-207.

Doumas, B.T., Watson, W.A. \& Biggs, H.G.1977. Albumin standards and the measurement of serum albumin with bromocresol green. Clinical Chemistry. Acta, 31:87-96.

Drzewiecki, J., Delgado-Licon, E., Haruenkit, R., Pawelzik, E., Martin-Belloso, O., Park, Y.S., Jung, S.T., Trakhtenberg, S. \& Gorinstein, S. 2003. Identification and differences of total proteins and their soluble fractions in some pseudo-cereals based on electrophoretic patterns. Journal of Agricultural and Food Chemistry, 51:7798-7804.

Emily, A.H., Pan, A., Malik, V.S. \& Sun, Q.2012. White rice consumption and risk of type 2 diabetes: meta-analysis and systematic review. BMJ, 344-352.

Foster-Powell, K., Holt, S.H. \& Brand-Miller, J.C. 2002. International table of glycemic index and glycemic load values. American Journal of Clinical nutrition, 76:5-56. 
Grant, G., More, L.J., McKenzie, N.H., Dorward, P.M., Buchan, W.C., Telek, L.\& Pusztai, A. 1995. Nutritional and haemagglutination properties of several tropical seeds. Journal of Agricultural Science, 124:437-445.

Güçlü-Üstündağ, Ö \& Mazza, G. 2007. Saponins: Properties, applications and processing. Critical Reviews in Food Science and Nutrition 47, 231-258.

Hafez, L.M. \& Mostafa, R.A.2014. Sensory, chemical and biological evaluation of gluten free products for celiac disease children. Egyptian Journal of Nutrition, 29:105-135.

Jacobsen, S.E. 2003. The worldwide potential of quinoa (Chenopodium quinoa Willd). Food Reviews International 19: 167-177.

Koziol, M.J. 1992. Chemical composition and nutritional evaluation of quinoa (Chenopodium quinoa Willd). Journal of Food Composition Analysis, 5: 35-68.

Koziol, M. 1993. Quinoa: A potential new oil crop. In: New crops (J. Janick \& J. E. Simon, Eds.), pp. 328-336. Wiley, New York.

Kunst, A., Draeger, B. \& Ziegenhom, J. 1984. In: Methods of Enzymatic Analysis, Bergmmeyer. Eds., 3rd ed. Volume VI, Metabolites1: Carbohydrates 163-172.

Lamb, E., Newman, D. \& Price, C. 2006. Kidney function tests In: Text Book of Clinical Chemistry and Molecular Diagnostics. 4th ed. Burtis CA, A shwood, E.R., Bruns, D.E. \& Tietz (Eds). St. Louis, MO: Elsevier Saunders, 797-835.

Lee, S.C., Prosky, L \& De Vries, J.W.1992. Determination of total, soluble, and insoluble dietary fiber in foods-Enzymatic-gravimetric method, MES-TRIS buffer: collaborative study. J. AOAC Int, 75:395-416.

Lohi, S., Mustalahti, K., Kaukinen, K., Laurila, K., Collin, P., Rissanen, H., Lohi, O., Bravi, E., Gasparin, M., Reunanen, A. \& Maki, M. 2007. Increasing prevalence of celiac disease over time. Alimentary Pharmacology and Therapeutics, 26:1217-1225.

Lucisano, M., Cappa, C., Fongaro, L. \& Mariotti, M. 2012. Characterisation of gluten free pasta through conventional and innovative methods: evaluation of the cooking behaviour. Journal of Cereal Science, 56:667-675.
Miranda, J., Lasa, A., Bustamante, M.A., Churruca, I. \& Simon, E. 2014. Nutritional differences between a gluten-free diet and a diet containing equivalent products with gluten. Plant Foods for Human Nutrition, 69:182-187.

Nascimento, A.C., Mota, C., Coelho, I., Gueifao, S., Santos, M., Matos, A.S., Gimenez, A., Lobo, M., Samman, N. \& Castanheira, I. 2014. Characterisation of nutrient profile of quinoa (Chenopodium quinoa), amaranth (Amaranthu scaudatus), and purple corn (Zea mays L.) consumed in the North of Argentina: proximate, minerals and trace elements. Food Chemistry, 148:420-426.

National Academy of Sciences.1995. Nutrient Requirements of Laboratory Animals. Fourth Revised Edition, chapter 2, National Academy Press, Washington, D.C.

National Academy of Sciences.2004. Comprehensive DRI table for vitamins, minerals and macronutrients, organized by age and gender. Institute of Medicine. Food and Nutrition Board, Beltsville, MD.

National Food Agency of Denmark.1996. Ministry of Health Institute of Food Chemistry and Nutrition. Determination of vitamin B1 and $\mathrm{B} 2$ by HPLC in Food and Feed method No.189.2.

National Institutes of Health. 2005. Guidelines for Rodent Transportation (12/09/15) and for Survival Bleeding of Mice and Rats (08/12/15).NIH-ARAC Guidelines [online] 2005.Jan12.Availablefrom:http://www.oacu. od.nih.gov/ARAC/ Bleeding. [Accessed on 2010 Mar 09].

Obadoni, B.O. \& Ochuko, P.O. 2001. Phytochemical studies and comparative efficacy of the crude extract of some homeostatic plants in Edo and Delta states of Nigeria. Global Journal of Pure and Applied Science, 8: 203- 208.

Obatolu, V., Ketiku, A. \& Adebowale, E. 2003. Effect of feeding maize / legume mixtures on biochemical indices in rats. Annals of Nutrition Metabolism, 47:170-175.

Oshodi, A., Ogungbenle, H., \& Oladimeji, M. 1999. Chemical composition, nutritionally valuable minerals and functional properties of benniseed (Sesamum Radiatum), pearl millet (Pennisetum Typhoides) and quinoa. International Journal of Food Sciences and Nutrition, 50:325-331. 
Packaged Facts. 2012. Gluten-Free Foods and Beverages in the U.S., 4th ed. (168 pages) Packaged Facts: Pub ID: LA4880536, A division of Market Research Group, LLC.

Paśko, P., Zagrodzki, P., Bartoń, H., Chłopicka, J. \& Gorinstein, S.h. 2010. Effect of Quinoa seeds (Chenopodium quinoa) in diet on some biochemical parameters and essential elements in blood of high fructose-fed rats. Plant Foods for Human Nutrition 65:333-338.

Pisani, T., Gebski, C. \& Leary, E. 1995.Accurate Direct Determination of Low-Density Lipoprotein Cholesterol Using an Immunoseparation Reagent and Enzymatic Cholesterol Assay. Archives of Pathology and Laboratory Medicine, 119:1127-1135.

Repo-Carrasco, R., Espinoza, C. \& Jacobsen, S. E., 2003. Nutritional value and use of the Andean crops quinoa (Chenopodium quinoa) and kañiwa (Chenopodium pallidicaule). Food Reviews International 19: 179-189.

Ruales, J. \& Nair, B.M. 1992. Nutritional quality of the protein in quinoa (Chenopodium quinoa, Willd) seeds. Plant Foods for Human Nutrition , 42: 1-11.

Ruales, J. \& Nair, B.M 1993. Content of fat, vitamins and minerals in quinoa (Chenopodium quinoa, Willd) seeds. Food Chemistry, 48:131-136.

Ryan, E., Galvin, K., O’Connor, T., Maguire, A., \& O'Brien, N. 2007. Phytosterol, squalene, tocopherol content and fatty acid profile of selected seeds, grains, and legumes. Plant Foods for Human Nutrition, 62: 85-91.

Statistical Analysis System (SAS) .2003.User's Guide: Statistics; version 9.1 Edition SAS Inst., Inc., Cary, NC, 27513, UAS.

Sugiuchi, H., Okabe, H. \& Irie, T. 1995. Direct Measurement of High Density Lipoprotein Cholesterol in Serum with Polyethylene Glycol Modified Enzymes and Sulfated $\alpha-\mathrm{Cy}-$ clodextrin. Clinical Chemistry, 41:717-723.
Takao, T., Watanabe, N., Yuhara, K., Itoh, S., Suda, S., Tsuruoka, Y., Nakatsugawa, K.\& Konishi, Y. 2005. Hypo cholesterolemic effect of protein isolated from quinoa (Chenopodium quinoa_Willd.) seeds. Food Science and Technology Research, 11: 161-167.

Thompson, T., Dennis, M., Higgins, L.A., Lee, A.R. \& Sharrett, M.K. 2005. Gluten-free diet survey: are Americans with celiac disease consuming recommended amounts of fiber, iron, calcium and grain foods? Journal of Human Nutrition and Dietetics, 18:163-169.

Tietz N., ed. 1995: Clinical Guide to Laboratory Tests, $3^{\text {rd }}$ ed. Philadelphia PA: WB Saunders Company. 130-131.

USDA U.S. Department of Agriculture, Agricultural Research Service. 2005. USDA National Nutrient Database for Standard Reference, Release 18.Nutrient Data Laboratory Home Page, http:/www.nal.usda.gov/fnic/foodcomp.

Valencia-Chamorro, S.A. 2003. Quinoa In: Caballero B.: Encyclopedia of Food Science and Nutrition. Vol 8. Academic Press, Amsterdam: 4895-4902.

Vega-Galvez, A., Miranda, M., Vergara, J., Uribe, E., Puente, L. \& Martinez, E.A. 2010. Nutrition facts and functional potential of quinoa (Chenopodium quinoa willd) an ancient Andean grain: a review. Journal of the Science of Food and Agriculture, 90:2541-2547.

Wahlefeld, A. \& Bergmeyer, H. Eds .1972: Methods of Enzymatic Analysis. Scand. Journal of Clinical Laboratory Investigation, 29 (126): Abstract 11\&12.

Walts, B.M., Ylimaki, G.L. Jeffrey, L.E. \& Elias, L.G. 1989. Sensory Method for Food Evaluation, IDRG, Ottawa, pp: 6-9, 60-79.

Wild, D., Robins, G.G., Burley, V.J. \& Howdle, P.D. 2010. Evidence of high sugar intake, low fiber and mineral intake in the glutenfree diet. Alimentary Pharmacology and Therapeutics, 32: 573-581. 


\section{التقييم الكيماوي والحيوي لبعض المتتجات المعلة من خلطات أساسها الكينوا

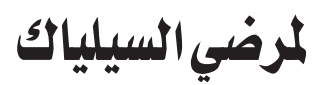

أشرف صابر السبيعي ، لمياء محمدل حافظ

المركز الإقليمي لكلاغذية والأعلاف - مركز البحوث الزر اعياءيه - الإسكندرية - مصر

مرض السيلياك واحد من الإضطر ابات الهضمية المزمنة الشائعة في جميع أنحاء العالم. حظيت الكينوا كطعام

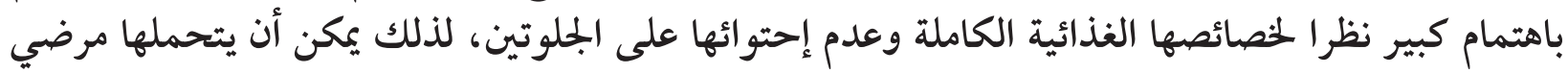

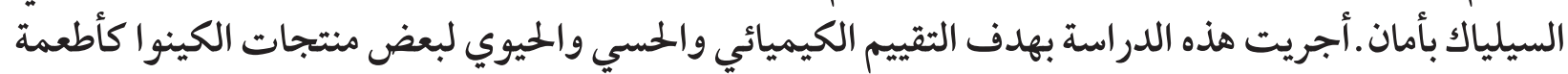

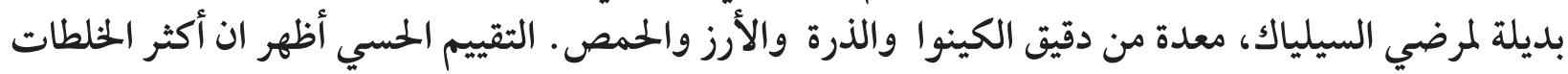

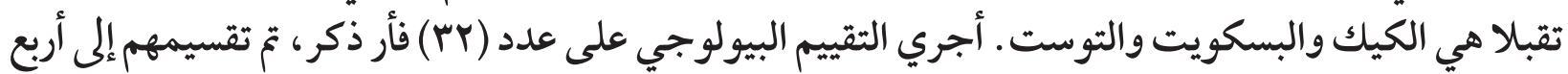

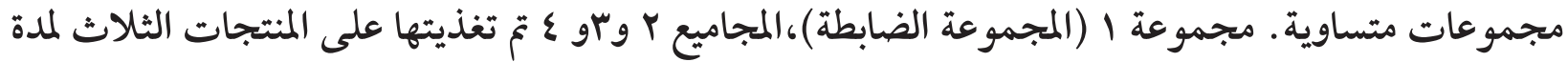

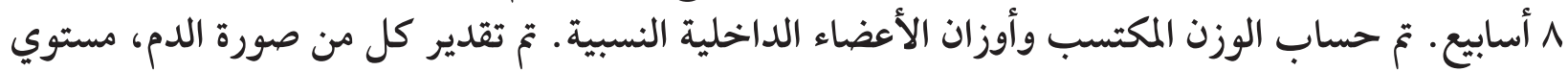
الدهون، وانزيمات الآلانين ترانس أمينيز و الأسبارتات ترانس أمينيز، البروتين الكلي، الألبومين، البيليروبين، البين،

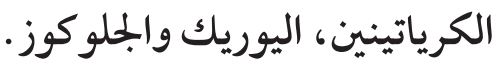

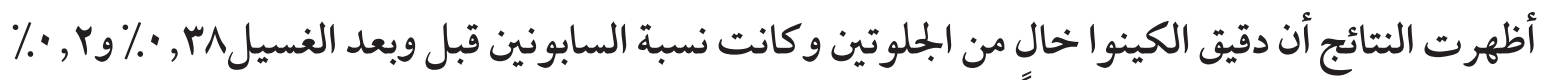

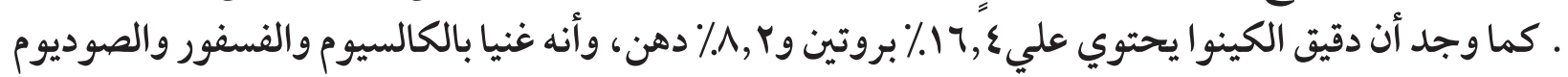

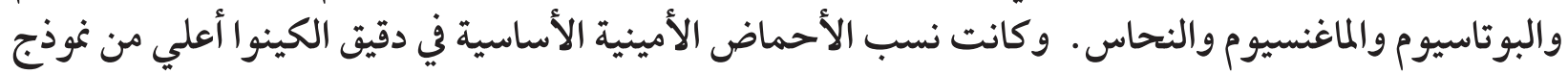

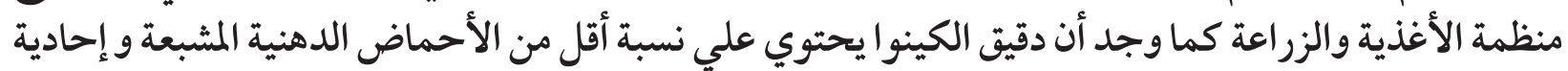

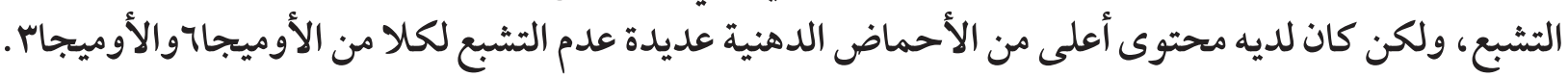

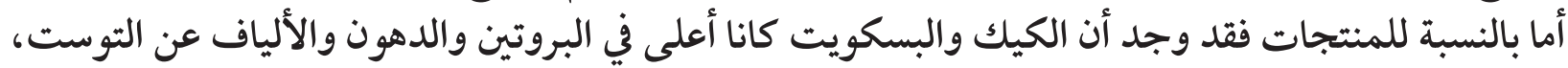

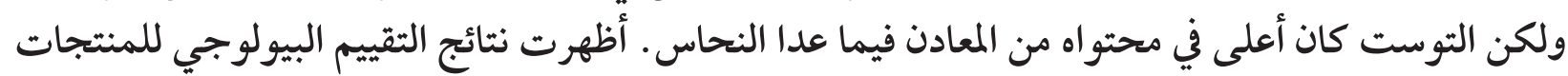

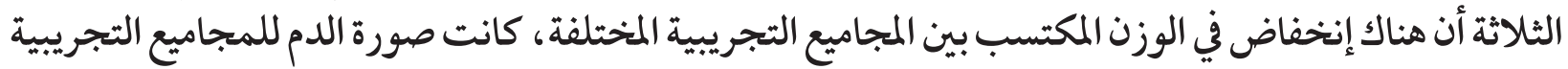

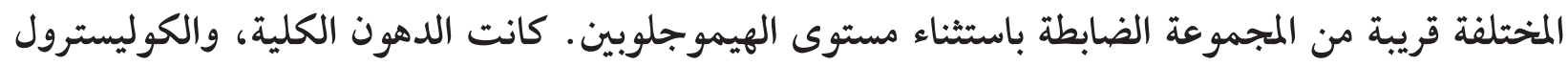

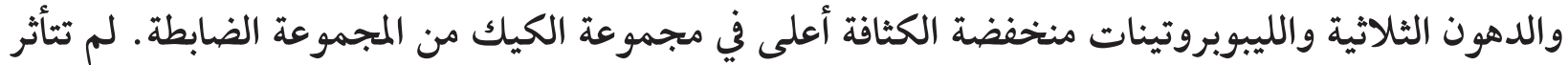

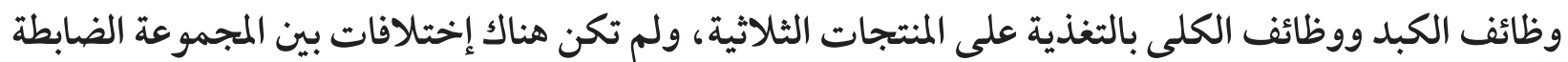

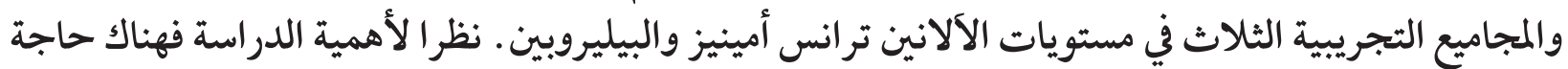

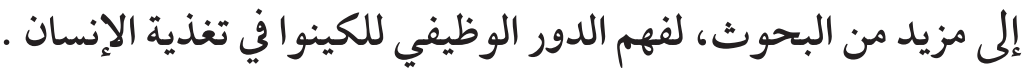

